\title{
ACTION OF METHYL JASMONATE AND SALT STRESS ON ANTIOXIDANT SYSTEM OF ARABIDOPSIS PLANTS DEFECTIVE IN JASMONATE SIGNALING GENES
}

\author{
T. O. YASTREB $B^{1}$ YU. E. KOLUPAEV $V^{1,2}$, N. V. SHVIDENKO', A. P. DMITRIEV \\ ${ }^{1}$ Dokuchaev Kharkiv National Agrarian University, Ukraine; \\ e-mail: plantbiology@ukr.net; \\ ${ }^{2}$ Karazin Kharkiv National University, Ukraine; \\ ${ }^{3}$ Institute of Cell Biology and Genetic Engineering, \\ National Academy of Sciences of Ukraine, Kyiv; \\ e-mail:dmitriev.ap@gmail.com
}

Role of jasmonate signaling in the regulation of stress-protective systems in Arabidopsis under salt stress remains insufficiently studied. For its clarification, comparative studies with mutants lacking various protein components of jasmonate signaling are advisable. In this connection, effects of methyl jasmonate (MJ, $50 \mu \mathrm{M})$ and salt stress $(\mathrm{NaCl}, 150 \mathrm{mM})$ on functioning of antioxidant and osmoprotective systems of wild-type Arabidopsis plants (Col-0) and ones defective in jasmonate signaling, namely coil (mutant for gene coding the protein COIl, which participates in removal of repressor proteins of transcription factors of jasmonate signaling) and jin1 (mutant defective in gene encoding the transcription factor JIN1/MYC2, one of the key in jasmonate signaling), were investigated. Salt stress inhibited growth of plants of all three genotypes. Treatment with MJ before salt stress positively influenced only the growth of wild-type plants. In contrast to mutants coil and jin1, Col-0 plants treated with MJ, under conditions of salt stress, kept close to the control values of water and total chlorophylls content, and the content of carotenoids increased. The coil plants under normal conditions differed from wild-type plants and jin1 mutants by reduced activity of guaiacol peroxidase and catalase and increased proline content. Treatment with MJ did not affect the activity of antioxidant enzymes and proline content in both mutants defective in jasmonate signaling. Under salt stress, the activity of superoxide dismutase, catalase and guaiacol peroxidase, as well as the content of proline and anthocyanins, in wildtype plants treated with MJ, were significantly higher than in control plants. The role of jasmonate-dependent protective systems in resistance of Arabidopsis plants to salt stress is discussed.

Ke y wo rds: Arabidopsis thaliana, coil, jinl, methyl jasmonate, signaling, salt stress, stress-protective systems.

A t present, specific proteins have been identified for the transduction of jasmonic acid (JA) signal into the genetic apparatus of plant cell [1, 2]. It is known that the physiological activity of JA is manifested after its transformation into jasmonoyl-L-isoleucine. In this regard, the JAR1 protein, displaying activity of aminoacyl synthetase, which conjugates amino acids with jasmonic acid, is considered as one of the first components of chain of transduction of its signal into the genetic apparatus [3]. At the same time, the COI1 protein, which is part of the SCF/COI1 complex conjugated with ubiquitin enzymes, is considered to be the jasmonate recep- tor specifically binding jasmonoyl-L-isoleucine [4]. An interaction of jasmonoyl-L-isoleucine with COI1 leads to its activation and interaction with JAZ- (Jasmonate-Zim-Domain) proteins, JA-signal repressors that are sent to 26S proteasomes for degradation [5]. Consequently, a signaling pathway of JA is opened for specific transcription factors MYC2, MYC3 and MYC4 [4]. It is believed that JIN1/MYC2 is one of the major positive regulators in jasmonate-inducible gene expression in Arabidopsis thaliana [5, 6].

Recently, JA and its derivatives are considered to be important regulators of plant resistance not only to biotic, but also to abiotic stresses, incl. to

(c) 2018 Yastreb T. O. et al. This is an open-access article distributed under the terms of the Creative Commons Attribution License, which permits unrestricted use, distribution, and reproduction in any medium, provided the original author and source are credited. 
salt $[7,8]$. Earlier, we showed less effective functioning of stress-protective systems under conditions of salt stress in Arabidopsis mutant jin1 treated with JA compared to wild-type plants [9]. However, the transcription factor JIN1/MYC2 is involved in the effects of not only JA but also abscisic acid (ABA) [10-13] and, probably, nitric oxide [14, 15]. Moreover, a number of studies have indicated the involvement of the transcription factor JIN1/MYC2, previously activated by jasmonate signal, in the regulation of ABA-dependent salt stress reactions [16]. Therefore, it remains unclear whether the low salt tolerance of the jinl mutants is due to the violation of jasmonate signaling, or the differences in salt tolerance of wildtype plants and the jin1 mutants are due to the involvement of the JIN1/MYC2 transcription factor in other signaling pathways. On the other hand, it is known that the transduction of jasmonate signal occurs not only with the help of the JIN1/MYC2 transcription factor, but also with the ERF family proteins (ERF1, ERF2, ERF5 and ERF6), which combine effects of JA and ethylene and are involved in regulation of expression of a number of genes $[5,17]$.

Thus, it is relevant to carry out comparative studies with mutants lacking various protein components in order to clarify the role of jasmonate signaling in the regulation of stress-protective systems of Arabidopsis under salt stress. Functioning of the antioxidant and osmoprotective systems in the Arabidopsis mutant defective in COI1 jasmonate receptor under salt stress has not yet been studied, although there are data indicating its role in regulating biosynthesis of flavonoid compounds, expression of non-specific peroxidase and ascorbate peroxidase genes $[18,19]$, which are important for adaptation to salinity and other stress factors.

In connection with the foregoing, the aim of the study was to compare the functioning of the antioxidant and osmoprotective systems of coil (coronatine insensitive 1) and jinl (jasmonate insensitive 1) mutants, defective in jasmonate signaling, and wildtype Arabidopsis thaliana plants under salt stress in the presence and absence of exogenous methyl jasmonate (MJ).

\section{Materials and Methods}

Five-week-old plants of Arabidopsis thaliana L. wild-type (Col-0) and coil and jin1 lines were used in experiments. Plants were grown in water culture on Hoagland medium with modifications [20] at $24 / 18{ }^{\circ} \mathrm{C}$ (day/night), illumination of 6000 lux and
$10 \mathrm{~h}$ photoperiod [9]. MJ (Sigma-Aldrich, USA) at a concentration $50 \mu \mathrm{M}$ was inserted into the culture medium and plants were incubated on it for $24 \mathrm{~h}$. The optimal concentration of MJ was determined in preliminary experiments, where the effect of 10$200 \mu \mathrm{M}$ MJ on growth parameters of Col-0 under the salt stress $(150 \mathrm{mM})$ was evaluated. At the end of the MJ treatment time, plants of three genotypes, treated and untreated with phytohormone, were subjected to salt stress by transferring to the medium supplemented with $150 \mathrm{mM} \mathrm{NaCl}$ and keeping for $24 \mathrm{~h}$.

For determination of the water content and biochemical analyzes, plates of mature leaves of the basal rosette were used. The assays were performed $24 \mathrm{~h}$ after the transfer of the plants to the medium with sodium chloride or to the nutrient medium without MJ.

The amount of water in the leaves was determined by the usual weighing method, drying the samples at $103{ }^{\circ} \mathrm{C}$ to a constant mass.

Photosynthetic pigments were extracted from the leaves with ethanol and their content was determined by spectrophotometric method [21]. The pigment content was expressed as $\mathrm{mg} / \mathrm{g}$ dry weight of the leaves.

The activity of antioxidant enzymes was determined by methods described in detail earlier [22]. The weighed leaves were homogenized in the cold in $0.15 \mathrm{M} \mathrm{K}$, Na-phosphate buffer ( $\mathrm{pH}$ 7.6) containing EDTA $(0.1 \mathrm{mM})$ and dithiothreitol $(1 \mathrm{mM})$. The homogenate was centrifuged at $8000 \mathrm{~g}$ for $10 \mathrm{~min}$ at $4{ }^{\circ} \mathrm{C}$ on MPW 350R centrifuge (Poland). The supernatant after centrifugation was used for the analysis. The activity of cytosolic superoxide dismutase (SOD, EC 1.15.1.1), represented predominantly by $\mathrm{Cu} / \mathrm{Zn}-\mathrm{SOD}$ [23], was determined at $\mathrm{pH} 7.6$ using a method based on the ability of the enzyme to compete with nitroblue tetrazolium for superoxide anions, formed due to the aerobic interaction of NADH and phenazine methosulfate. Catalase activity (EC 1.11.1.6) was determined at $\mathrm{pH} 7.0$ by the amount of decomposed hydrogen peroxide per unit of time. The activity of guaiacol peroxidase (EC 1.11.1.7) was determined using guaiacol as the hydrogen donor and hydrogen peroxide as the substrate. The activity of SOD and guaiacol peroxidase was expressed as arbitrary units/(g dry weight·min), catalase activity - as $\mathrm{mM} \mathrm{H}_{2} \mathrm{O}_{2} /$ (g dry weight-min).

The proline content in the leaves was analyzed using a ninhydrin reagent according to Bates et al. [24] and expressed as $\mu \mathrm{M} / \mathrm{g}$ dry weight. 
To determine the content of anthocyanins, the weighed plant material was homogenized in $1 \% \mathrm{HCl}$ solution in methanol [25]. After centrifugation of the homogenate at $8000 \mathrm{~g}$ for $15 \mathrm{~min}$, the optical density of the supernatant was determined at 530 and $657 \mathrm{~nm}$. When calculating the content of anthocyanins, the amount of nonspecific absorption at $657 \mathrm{~nm}$ was taken into account [26]. The content of anthocyanins was expressed in conventional units as the value $\left(\mathrm{A}_{530}-0.25 \mathrm{~A}_{657}\right) / \mathrm{g}$ dry weight.

The experiments were performed in triplicate biological replication and each experiment was independently reproduced 3 times. The data are presented as mean values and standard errors and are considered significant at $P \leq 0.05$ except the specially stipulated cases. The significance of the differences was evaluated by Student's $t$-test.

\section{Results and Discussion}

Growth indicators of plants under conditions of salt stress. Under the action of $150 \mathrm{mM} \mathrm{NaCl}$, a decrease in the growth of biomass of wild-type plants and both Arabidopsis mutants defective in jasmonate signaling was observed (Fig. 1). Treatment with MJ under conditions of salt stress improved the growth of wild-type plants and did not have a positive effect on growth rates of coil and jin1 mutants.

Water content in leaves under salt stress conditions. Under normal conditions, the water content in plant leaves of different genotypes did not differ significantly (Table). Treatment with MJ did not affect its content under these conditions. After salt stress, the water content in leaves of plants of all genotypes decreased. Pre-treatment with MJ promoted the maintenance of water proportion close to normal in the wild-type plants under salt stress. At the same time, it did not significantly affect the water content in leaves of both mutants defective in jasmonate signaling (Table).

Content of photosynthetic pigments in leaves. It is known that one of the markers of plant resistance to the action of stress factors, incl. salinity, is the



Fig. 1. Growth of biomass of Arabidopsis plants under salt stress (150 $\mathrm{mM} \mathrm{NaCl})$. Here and in Fig. 2-4: 1 - Col-0 (control); 2 - Col-0 (methyl jasmonate, $50 \mu \mathrm{M}) ; 3$ - coil (control); 4 - coil (methyl jasmonate, $50 \mu M$ ); 5 -jin1 (control); 6 -jin1 (methyl jasmonate, $50 \mu \mathrm{M}$ ); values with the same superscript letters are not significantly different $(P \leq 0.05)$

ability to preserve a pool of photosynthetic pigments [27]. The content of chlorophylls and carotenoids in leaves of Arabidopsis of three genotypes did not differ significantly under normal conditions (Fig. 2). In the absence of salt stress, the treatment of plants with MJ did not significantly affect the content of photosynthetic pigments.

Under the influence of salt stress, the chlorophylls content in plants of all genotypes decreased. Treatment with MJ contributed to the preservation of the chlorophylls pool in wild-type plants and did not significantly affect its value in coil and jinl genotypes (Fig. 2). Also under salt stress conditions, MJ treatment promoted an increase in the content of carotenoids in leaves of Col-0 plants.

Activity of antioxidant enzymes in plant leaves. The activity of the key antioxidant defense enzyme, SOD, in the various genotypes of Arabidopsis under normal conditions somewhat differed (Fig. 3, A).

Water content in leaves of Arabidopsis plants (\%)

\begin{tabular}{l|c|c|c|c}
\hline Genotype & Control & Methyl jasmonate $(50 \mu \mathrm{M})$ & $\mathrm{NaCl}(150 \mathrm{mM})$ & $\begin{array}{c}\text { Methyl jasmonate }(50 \mu \mathrm{M}) \\
+\mathrm{NaCl}(150 \mathrm{mM})\end{array}$ \\
\hline Col-0 & $91.30 \pm 0.21^{\mathrm{a}}$ & $91.00 \pm 0.24^{\mathrm{a}}$ & $88.60 \pm 0.22^{\mathrm{b}}$ & $91.6 \pm 0.2^{\mathrm{a}}$ \\
coi1 & $92.0 \pm 0.2^{\mathrm{a}}$ & $91.80 \pm 0.28^{\mathrm{a}}$ & $89.30 \pm 0.32^{\mathrm{b}}$ & $89.50 \pm 0.25^{\mathrm{b}}$ \\
jin1 & $92.10 \pm 0.27^{\mathrm{a}}$ & $91.5 \pm 0.3^{\mathrm{a}}$ & $89.70 \pm 0.25^{\mathrm{b}}$ & $90.20 \pm 0.22^{\mathrm{a}, \mathrm{b}}$ \\
\hline
\end{tabular}

Values with the same superscript letters are not significantly different $(P \leq 0.05)$ 

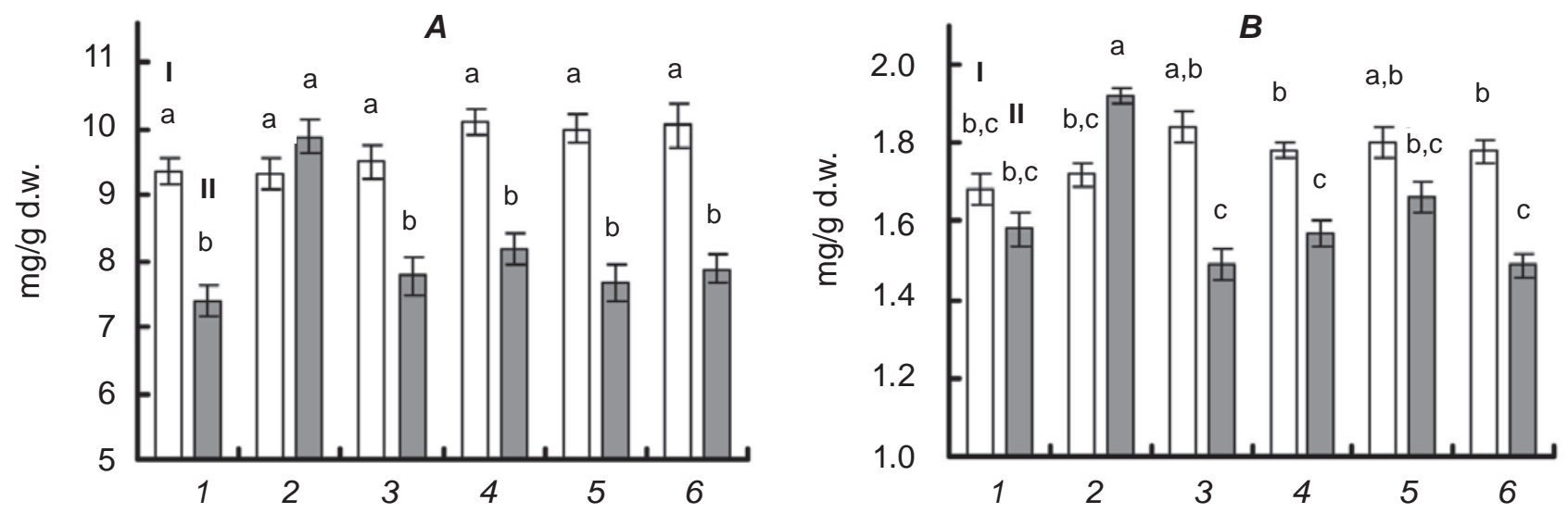

Fig. 2. Content of chlorophyll (A) and carotenoids (B) in leaves of Arabidopsis. Here and in Fig. 3-4: I-without stress, II - NaCl (150 mM)
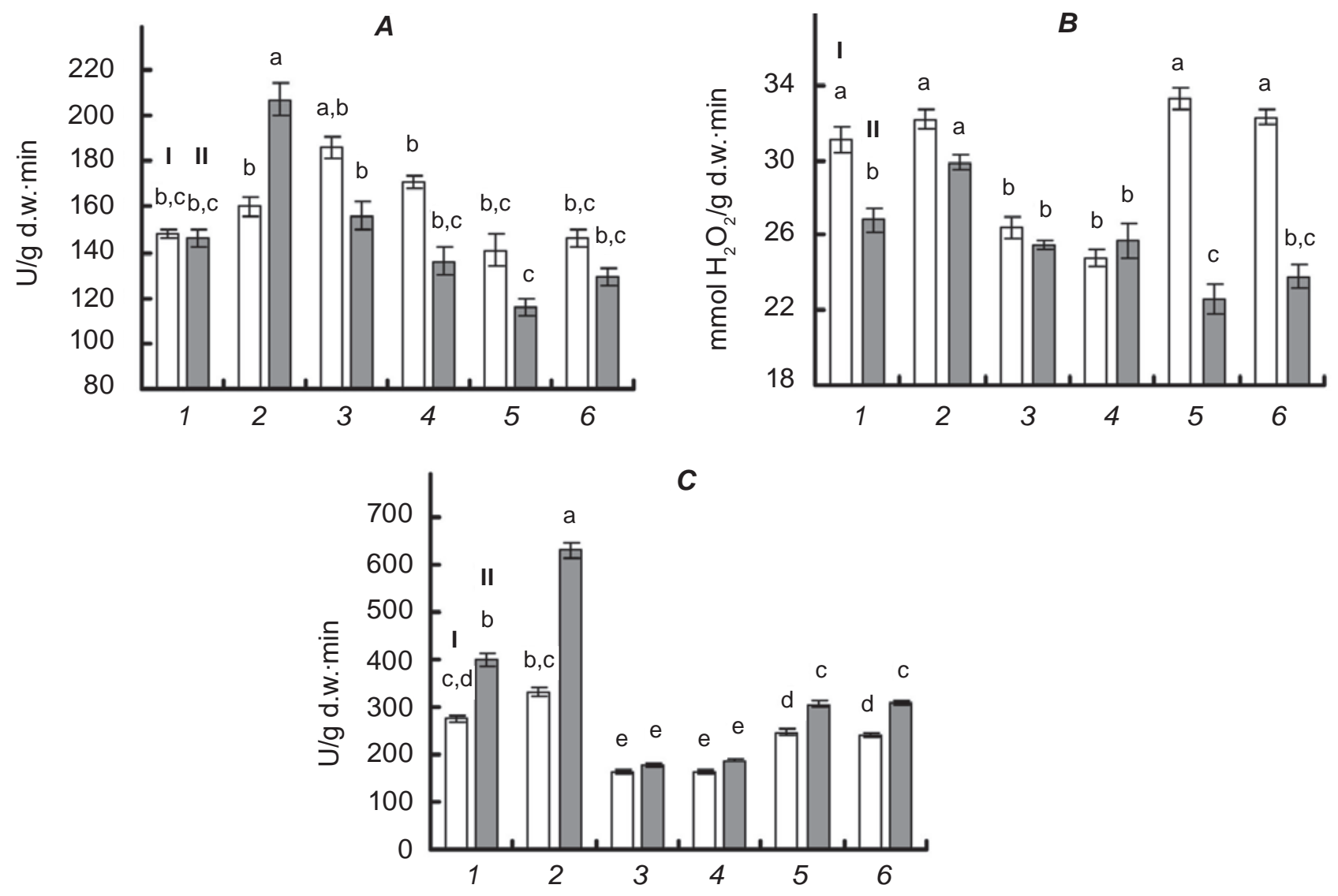

Fig. 3. Activity of SOD (A), catalase (B) and guaiacol peroxidase (C) in leaves of Arabidopsis

Thus, its value in coi1 plants was higher than that in wild-type plants. Treatment with MJ in the absence of stress did not significantly affect the enzyme activity in leaves of plants of all the investigated genotypes.

Under salt stress, the SOD activity in wild-type plants did not change significantly, but it decreased slightly in mutants defective in jasmonate signaling (Fig. 3, A). Treatment with MJ caused an increase in the activity of SOD under salt stress only in wildtype plants.

The catalase activity under physiologically normal conditions in plants of the jinl genotype did not differ from that in the wild-type, while at the same 
time it was noticeably lower in coi1 plants (Fig. 3, B). Treatment with MJ had no effect on catalase activity in all three genotypes in the absence of stress.

Under the influence of salt stress, the enzyme activity was significantly reduced in jinl plants and to a lesser extent in wild-type plants. In coi1 plants, it did not change significantly. Treatment with MJ contributed to the preservation of values of catalase activity, characteristic to normal conditions, in wildtype plants (Fig. 3, B).

Basic values of the activity of guaiacol peroxidase in Arabidopsis plants of different genotypes differed markedly (Fig. 3, C). Thus, in jinl and especially coil plants, it was lower in comparison with the value of wild-type plants. Treatment with MJ promoted an increase in the activity of the enzyme in wild-type plants and did not affect its values in mutants defective in jasmonate signaling.

Under salt stress, the activity of guaiacol peroxidase increased in wild-type plants and to a lesser extent in the jin1 mutants, and in the coil mutant it remained low. Treatment with MJ caused an additional increase in the enzyme activity in wild-type plants after salt stress (Fig. 3, C).

Proline content in leaves. Under physiologically normal conditions, the amount of proline in leaves of coi1 mutants was approximately twice as high as in wild-type plants and in the jinl mutants (Fig. 4, A). In the absence of stress, MJ treatment did not cause changes in proline content in all three genotypes.

In MJ-untreated Col-0 plants, under salt stress, the proline content increased more than 4-fold, and in plants pretreated with phytohormone it increased approximately 6-fold. The jin 1 and coi1 mutants also showed an increase in proline content in response to salt stress, but pretreatment with MJ did not significantly affect its amount (Fig. 4, A).

Content of anthocyanins in leaves. Under normal conditions, the content of anthocyanins in plants of all three genotypes did not differ (Fig. 4, B). Treatment with $\mathrm{MJ}$ caused its increase in wild-type plants, but did not affect this index in coil and jin1 mutants.

After salt stress, the content of anthocyanins in plants of three genotypes decreased. MJ treatment mitigated this effect only in Col-0 plants (Fig. 4, B).

Jasmonate-dependent regulation of protective systems in Arabidopsis plants. Discussing the results, first of all, it should be noted that there are noticeable differences in biochemical indicators studied in Arabidopsis plants of different genotypes. Thus, the Arabidopsis coil mutant differed from wild-type plants by a higher SOD activity, but reduced catalase and especially guaiacol peroxidase activities (Fig. 3). Also, for these plants, characteristic proline content was higher than in other genotypes (Fig. 4, $A$ ). It can be assumed that an increase in the proline content, which has antioxidant properties [28], compensates to a certain extent the low activity of enzymes that destroy hydrogen peroxide for the plants of this genotype (Fig. 3). The literature describes the effects of functional interaction of enzymatic antioxidants and proline, as well as their interchangeability [29]. Note that the differences in biochemical parameters in the jinl mutants from those in wild-type plants were not as significant as those of the coil mutants. Apparently, the closure of jasmonate signal associated with the coi1 mutation (gene coding the jasmonate receptor COI1) is more stringent than the jin1 mutation. This may be due to the fact that other
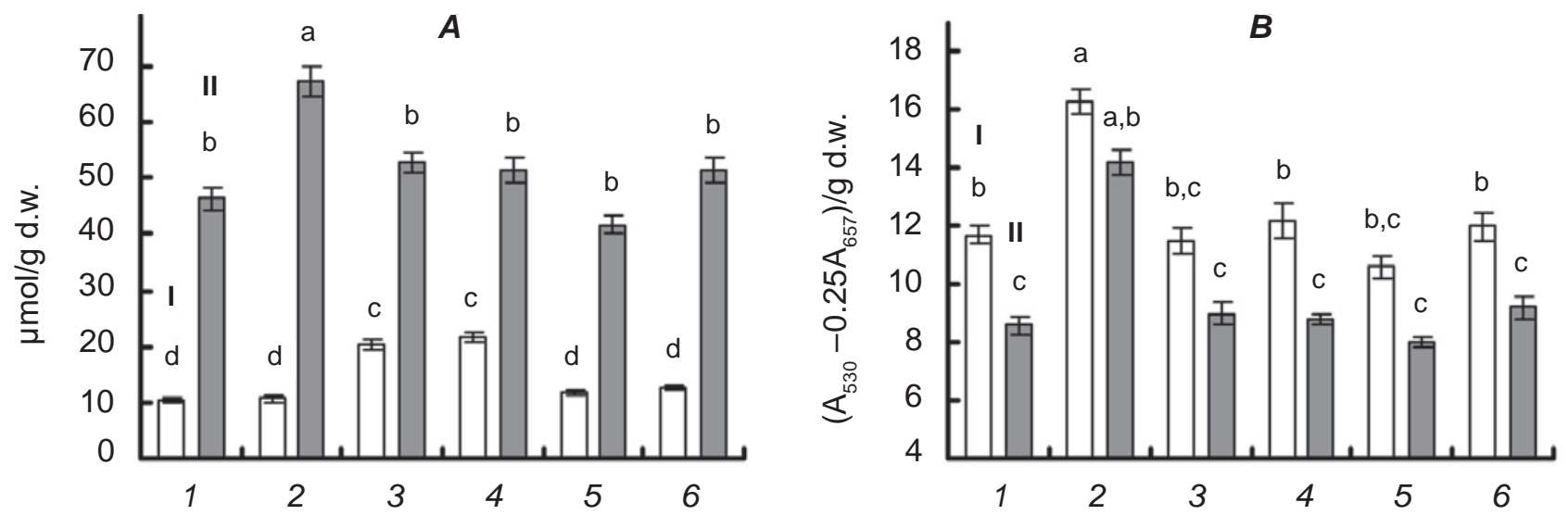

Fig. 4. Proline (A) and anthocyanins (B) content in leaves of Arabidopsis 
protein components are involved in transfer of jasmonate signal to genetic apparatus, in particular, the already mentioned ERF protein [5]. It is possible that the presence of alternative transcription factors in jin1 plants can provide a partial transduction of the jasmonate signal in genetic apparatus. So, after pretreatment with MJ, these plants showed a tendency to increase the proline content on the background of salt stress (Fig. 4, A). Under stress conditions, the activity of guaiacol peroxidase increased in jinl plants (Fig. 3, C). Such effects were not characteristic for coil mutants defective in the gene encoding the immediate receptor of jasmonate.

On the whole, in both mutants defective in jasmonate signaling (coil and jinl), after MJ treatment, unlike wild-type plants, there was practically no increase in salt tolerance. This was expressed in the absence of a positive effect of MJ on the growth, water and photosynthetic pigments content in these genotypes under salt stress (Fig. 1, 2, Table). In literature, there are data on the participation of proteins both COI1 [18] and JIN1/MYC2 [6] in the positive regulation of flavonoid content, incl. anthocyanins. The jasmonate signal appears to be important for the regulation of the prolin content, a multifunctional protector participating in osmoregulation, antioxidant protection and maintenance of protein functional activity under salt stress [28]. Thus, the proline content in soybean leaves [30] and banana fruits [31] increased under the influence of exogenous MJ. A positive relationship was established between expression level of JIN1/MYC2 gene and accumulation of proline. It is noteworthy that proline can have a positive effect on the accumulation of anthocyanins in plants under stress conditions [32]. However, the mechanisms of this influence are still unclear. In the conditions of our experiments, wild-type Arabidopsis plants treated with MJ under conditions of salt stress showed an increased proline content and a pool of anthocyanins was preserved (Fig. 4), that probably prevented oxidative damage.

An important component of the effect of jasmonate under salt stress, apparently, is its participa- tion in the regulation of antioxidant enzyme activity. As already noted, in both jasmonate signaling mutants, jin1 and especially coil, a decreased activity of enzymes that neutralize hydrogen peroxide was observed (Fig. 3). Treatment with exogenous MJ promoted an increase in the activity of SOD, guaiacol peroxidase and preservation of catalase activity only in wild-type Arabidopsis plants, but not these mutants. It should be noted that an increase in the activity of antioxidant enzymes under the influence of JA was also shown in a number of other objects [33-35]. It was also reported that JA and MJ induced the emergence of new molecular forms of SOD and peroxidase in leaves of wheat and castor plants [33, 36].

Thus, jasmonic acid and its derivatives appear to be involved in the regulation of functioning of complex of protective systems, including antioxidant enzymes, proline, flavonoid compounds, under an action of stressors (including salinity). Transduction of jasmonate signal regulating these systems includes protein complexes containing COI1 and JIN1/ MYC2. However, it is possible that part of the physiological (stress-protective) effects of jasmonate can be realized without the participation of transcription factors of the MYC family, for example, with ERF proteins involved in the ethylene signaling [5]. On the other hand, as already noted, the transcription factors of the MYC family can be involved in the transduction of signals not only of jasmonate, but also ABA and NO, which are also involved in plant adaptation to salinity. In addition, ROS, lipid signaling components and other mediators can participate in the realization of jasmonate effects $[34,35]$. Their possible functional interaction with the main components of jasmonate signaling, in particular, with proteins COI1 and MYC2, remains unexplored.

The publication contains the results of the studies supported by the grant of the President of Ukraine for competitive projects F70/136-2017 of the State Fund for Fundamental Research. 


\section{ДІЯ МЕТИЛЖАСМОНАТУ І СОЛЬОВОГО СТРЕСУ НА АНТИОКСИДАНТНУ СИСТЕМУ РОСЛИН АРАБІДОПСИСУ, ДЕФЕКТНИХ ЗА ГЕНАМИ ЖАСМОНАТНОГО СИГНАЛІНГУ}

\section{Т. О. Ястреб} М. В. Швиденко ${ }^{1}$ О. П. Дмитрієв

\author{
${ }^{1}$ Харківський національний аграрний \\ університет ім. В. В. Докучаєва, Україна; \\ e-mail: plant_biology@ukr.net; \\ ${ }^{2}$ Харківський національний університет \\ ім. В. Н. Каразіна, Україна; \\ ${ }^{3}$ Інститут клітинної біології та генетичної \\ інженерії НАН України, Київ; \\ e-mail: dmitriev.ap@gmail.com
}

Роль жасмонатного сигналінгу в регуляції стреспротекторних систем арабідопсису за сольового стресу залишається недостатньо вивченою. Для iï з'ясування доцільні порівняльні дослідження 3 мутантами за різними протеїновими компонентами жасмонатного сигналінгу. У зв'язку з цим досліджували вплив метилжасмонату (МЖ, 50 мкМ) і сольового стресу (150 мM NaCl) на функціонування антиоксидантної та осмопротекторної систем рослин арабідопсису дикого типу (Col-0) i дефектних за жасмонатним сигналінгом: coi1 (мутант за геном, що кодує протеїн COI1, який бере участь у видаленні протеїнів-репресорів транскрипційних факторів жасмонатного сигналінгу) i jinl (мутант, дефектний за геном, що кодує транскрипційний фактор JIN1/MYC2 один із ключових у жасмонатному сигналінгу). Сольовий стрес інгібував ріст рослин всіх трьох генотипів. Обробка МЖ перед сольовим стресом позитивно впливала тільки на ріст рослин дикого типу. Також у рослин Col-0, оброблених МЖ, на відміну від мутантів соі1 і jinl, в умовах сольового стресу зберігалися близькі до контролю величини вмісту води, сумарного вмісту хлорофілів і підвищувався вміст каротиноїдів. Рослини генотипу coi1 у звичайних умовах відрізнялися від рослин дикого типу і мутантів jinl зниженою активністю гваяколпероксидази і каталази і підвищеним вмістом проліну. Обробка МЖ не впливала на активність антиоксидантних ензимів і вміст проліну в обох мутантів, дефектних за жасмонатним сигналінгом. За сольового стресу показники активності суперок- сиддисмутази, каталази і гваяколпероксидази, а також вмісту проліну і антоціанів у рослин дикого типу, оброблених МЖ, були помітно вищими, ніж у контрольних. Обговорюється роль жасмонатзалежних протекторних систем у забезпеченні стійкості рослин арабідопсису до сольового стресу.

Ключові слова: Arabidopsis thaliana, coi1, jin1, метилжасмонат, сигналінг, сольовий стрес, стреспротекторні системи.

\section{ДЕЙСТВИЕ МЕТИЛЖАСМОНАТА И СОЛЕВОГО СТРЕССА НА АНТИОКСИДАНТНУЮ СИСТЕМУ РАСТЕНИЙ АРАБИДОПСИСА, ДЕФЕКТНЫХ ПО ГЕНАМ ЖАСМОНАТНОГО СИГНАЛИНГА}

T. О. Ястреб ${ }^{1}$, Ю. Е. Колупаев ${ }^{1,2}$, Н. В. Швиденко , А. П. Дмитриев

${ }^{1}$ Харьковский национальный аграрный университет им. В. В. Докучаева, Украина; e-mail: plant_biology@ukr.net;

${ }^{2}$ Харьковский национальный университет им. В. Н. Каразина, Украина;

${ }^{3}$ Институт клеточной биологии и генетической инженерии НАН Украины, Киев; e-mail: dmitriev.ap@gmail.com

Роль жасмонатного сигналинга в регуляции стресспротекторных систем арабидопсиса при солевом стрессе остается недостаточно изученной. Для ее выяснения целесообразны сравнительные исследования с мутантами по различным протеиновым компонентам жасмонатного сигналинга. В связи с этим исследовали влияние метилжасмоната (МЖ, 50 мкМ) и солевого стресса (150 мМ NaCl) на функционирование антиоксидантной и осмопротекторной систем растений арабидопсиса дикого типа (Col-0) и дефектных по жасмонатному сигналингу: coi1 (мутант по гену, кодирующему протеин COI1, который участвует в удалении протеинов-репрессоров транскрипционных факторов жасмонатного сигналинга) и jinl (мутант, дефектный по гену, кодирующему транскрипционный фактор JIN1/MYC2 - один из ключевых в жасмонатном сигналинге). Солевой стресс ингибировал рост растений всех трех генотипов. Обработка МЖ перед солевым стрессом положительно влияла только на рост растений дикого типа. Также у растений Col-0, обработанных МЖ, в 
отличие от мутантов coil и jinl, в условиях солевого стресса сохранялись близкие к контролю величины содержания воды, суммарного содержания хлорофиллов и повышалось содержание каротиноидов. Растения генотипа coi1 в обычных условиях отличались от растений дикого типа и мутантов jinl пониженной активностью гваяколпероксидазы и каталазы и повышенным содержанием пролина. Обработка МЖ не влияла на активность антиоксидантных энзимов и содержание пролина у обоих мутантов, дефектных по жасмонатному сигналингу. При солевом стрессе показатели активности супероксиддисмутазы, каталазы и гваяколпероксидазы, а также содержания пролина и антоцианов у растений дикого типа, обработанных МЖ, были заметно выше, чем у контрольных. Обсуждается роль жасмонатзависимых протекторных систем в обеспечении устойчивости растений арабидопсиса к солевому стрессу.

К л юче вы е с ло в а: Arabidopsis thaliana, coi1, jin1, метилжасмонат, сигналинг, солевой стресс, стресспротекторные системы.

\section{References}

1. Wasternack C, Hause B. Jasmonates: biosynthesis, perception, signal transduction and action in plant stress response, growth and development. An update to the 2007 review in Annals of Botany. Ann Bot. 2013; 111(6): 10211058.

2. Kazan K. Diverse roles of jasmonates and ethylene in abiotic stress tolerance. Trends Plant Sci. 2015; 20(4): 219-229.

3. Staswick PE, Tiryaki I. The oxylipin signal jasmonic acid is activated by an enzyme that conjugates it to isoleucine in Arabidopsis. Plant Cell. 2004; 16(8): 2117-2127.

4. Lackman P, González-Guzmán M, Tilleman S, Carqueijeiro I, Pérez AC, Moses T, Seo M, Kanno Y, Häkkinen ST, Van Montagu MC, Thevelein JM, Maaheimo H, OksmanCaldentey KM, Rodriguez PL, Rischer H, Goossens A. Jasmonate signaling involves the abscisic acid receptor PYL4 to regulate metabolic reprogramming in Arabidopsis and tobacco. Proc Natl Acad Sci USA. 2011; 108(14): 5891-5896.

5. Santino A, Taurino M, De Domenico S, Bonsegna S, Poltronieri P, Pastor V, Flors V.
Jasmonate signaling in plant development and defense response to multiple (a)biotic stresses. Plant Cell Rep. 2013; 32(7): 1085-1098.

6. Dombrecht B, Xue GP, Sprague SJ, Kirkegaard JA, Ross JJ, Reid JB, Fitt GP, Sewelam N, Schenk PM, Manners JM, Kazan K. MYC2 differentially modulates diverse jasmonate-dependent functions in Arabidopsis. Plant Cell. 2007; 19(7): 2225-2245.

7. Ismail A, Riemann M, Nick P. The jasmonate pathway mediates salt tolerance in grapevines. $J$ Exp Bot. 2012; 63(5): 2127-2139.

8. Dar TA, Uddin M, Khan MMA, Hakeem KR, Jaleel H. Jasmonates counter plant stress: A Review. Environ Exp Bot. 2015; 115: 49-57.

9. Yastreb TO, Kolupaev YuE, Lugovaya AA, Dmitriev AP. Content of osmolytes and flavonoids under salt stress in Arabidopsis thaliana plants defective in jasmonate signaling. Appl Biochem Microbiol. 2016; 52(2): 210-215.

10. Lorenzo O, Chico JM, Sanchez-Serrano JJ, Solan R. Jasmonate-insensitive1 encodes a MYC transcription factor essential to discriminate between different jasmonate-regulated defence responses in Arabidopsis. Plant Cell. 2004; 16(7): 1938-1950.

11. Yadav V, Mallappa C, Gangappa SN, Bhatia S, Chattopadhyay S. A basic helix-loop-helix transcription factor in Arabidopsis, MYC2, acts as a repressor of blue light-mediated photomorphogenic growth. Plant Cell. 2005; 17(7): 1953-1966.

12. Fujita Y, Fujita M, Shinozaki K, YamaguchiShinozaki K. ABA-mediated transcriptional regulation in response to osmotic stress in plants. J Plant Res. 2011; 124(4): 509-525.

13. Yastreb TO, Kolupaev YuE, Lugovaya AA, Dmitriev AP. Formation of adaptive reactions in Arabidopsis thaliana wild-type and mutant jin1 plants under action of abscisic acid and salt stress. Cytol Genet. 2017; 51(5): 325-330.

14. Palmieri MC, Sell S, Huang X, Scherf M, Werner T, Durner J, Lindermayr C. Nitric oxideresponsive genes and promoters in Arabidopsis thaliana: a bioinformatics approach. J Exp Bot. 2008; 59(2): 177-186.

15. Yastreb TO, Kolupaev YuE, Karpets YuV, Dmitriev AP. Effect of nitric oxide donor on salt resistance of Arabidopsis jin1 mutants and wildtype plants. Russ J Plant Physiol. 2017; 64(2): 207-214. 
16. Ryu H, Cho YG. Plant hormones in salt stress tolerance. J Plant Biol. 2015; 58(3): 147-155.

17. Lorenzo O, Piqueras R, Sánchez-Serrano JJ, Solano R. Ethylene Response Factorl integrates signals from ethylene and jasmonate pathways in plant defense. Plant Cell. 2003; 15(1): 165-178.

18. Devoto A, Ellis C, Magusin A, Chang HS, Chilcott C, Zhu T, Turner JG. Expression profiling reveals COI1 to be a key regulator of genes involved in wound- and methyl jasmonateinduced secondary metabolism, defence, and hormone interactions. Plant Mol Biol. 2005; 58(4): 497-513.

19. Chen Y, Pang Q, Dai S, Wang Y, Chen S, Yan X. Proteomic identification of differentially expressed proteins in Arabidopsis in response to methyl jasmonate. J Plant Physiol. 2011; 168(10): 995-1008.

20. Semchuk NM, Vasylyk YuV, Lushchak OV, Lushchak VI.Effect of short-term salt stress on oxidative stress markers and antioxidant enzymes activity in tocopherol-deficient Arabidopsis thaliana plants. Ukr Biokhim Zhurn. 2012; 84(4): 41-48.

21. Shlyk AA. Determination of chlorophylls and carotenoids in extracts of green leaves. Biochemical Methods in Plant Physiology. Ed. Pavlinova OA. M.: Nauka, 1971: 154-170. (In Russian).

22. Kolupaev YuE, Ryabchun NI, Vayner AA, Yastreb TO, Oboznyi AI. Antioxidant enzyme activity and osmolyte content in winter cereal seedlings under hardening and cryostress. Russ J Plant Physiol. 2015; 62(4): 499-506.

23. Alscher RG, Erturk N, Heath LS. Role of superoxide dismutases (SODs) in controlling oxidative stress in plants. $J$ Exp Bot. 2002; 53(372): 1331-1341.

24. Bates LS, Walden RP, Tear GD. Rapid determination of free proline for water stress studies. Plant Soil. 1973; 39(1): 205-207.

25. Nogués S, Baker NR. Effects of drought on photosynthesis in Mediterranean plants grown under enhanced UV-B radiation. J Exp Bot. 2000; 51(348): 1309-1317.
26. Pietrini F, Massacci A. Leaf anthocyanin content changes in Zea mays L. grown at low temperature: Significance for the relationship between the quantum yield of PS II and the apparent quantum yield of $\mathrm{CO}_{2}$ assimilation. Photosynthesis Res. 1998; 58(3): 213-219.

27. Santos CV. Regulation of chlorophyll biosynthesis and degradation by salt stress in sunflower leaves. Sci Horticult. 2004; 103(1): 93-99.

28. Liang X, Zhang L, Natarajan SK, Becker DF. Proline mechanisms of stress survival. Antioxid Redox Signal. 2013; 19(9): 998-1011.

29. Radyukina NL, Ivanov YuV, Kartashov AV, Shevyakova NI, Rakitin VYu, Khryanin VN, Kuznetsov VIV. Inducible and constitutive mechanisms of salt stress resistance in Geum urbanum L. Russ J Plant Physiol. 2007; 54(5): 612-618.

30. Sheteawi SA. Improving growth and yield of salt-stressed soybean by exogenous application of jasmonic acid and ascobin. Int J Agri Biol. 2007; 9(3): 473-478.

31. Zhao ML, Wang JN, Shan W, Fan JG, Kuang JF, Wu KQ, Li XP, Chen WX, He FY, Chen JY, $\mathrm{Lu}$ WJ. Induction of jasmonate signalling regulators MaMYC2s and their physical interactions with MaICE1 in methyl jasmonateinduced chilling tolerance in banana fruit. Plant Cell Environ. 2013; 36(1): 30-51.

32. Kumchai J, Huang JZ, Lee CY, Chen FC, Chin SW. Proline partially overcomes excess molybdenum toxicity in cabbage seedlings grown in vitro. Genet Mol Res. 2013; 12(4): 5589-5601.

33. Sasaki-Sekimoto Y, Taki N, Obayashi T, Aono M, Matsumoto F, Sakurai N, Suzuki H, Hirai MY, Noji M, Saito K, Masuda T, Takamiya K, Shibata D, Ohta H. Coordinated activation of metabolic pathways for antioxidants and defence compounds by jasmonates and their roles in stress tolerance in Arabidopsis. Plant J. 2005; 44(4): 653-668.

34. Kalachova TA, Iakovenko OM, Kretinin SV, Kravets VS. Effects of salicylic and jasmonic acid on phospholipase D activity and the level 
of active oxygen species in soybean seedlings. Biochemistry (Mosc) Suppl Ser A: Membrane Cell Biol. 2012; 6(3): 243-248.

35. Karpets YuV, Kolupaev YuE, Yastreb TO, Oboznyi OI, Shvydenko MV, Lugova GA, Vayner AO. Reactive oxygen forms and $\mathrm{Ca}$ ions as possible intermediaries under the induction of heat resistance of plant cells by jasmonic acid. Ukr Biokhim Zhurn. 2013; 85(3): 62-68. (In Russian).

36. Wolucka BA, Goossens A, Inzé D. Methyl jasmonate stimulates the de novo biosynthesis of vitamin C in plant cell suspensions. $J$ Exp Bot. 2005; 56(419): 2527-2538.

Received 10.05.2018 